Watson ${ }^{3}$. Data for two soils are appended. On soil $A$ pining in sheep has definitely been both prevented and cured by the application of $2 \mathrm{lb}$. cobalt chloride per acre, and, although the molybdenum content of the herbage increases as a result of cobalt treatment, even 10 lb. per acre, a dressing considerably greater than any likely to be used in practice, does not increase the molybdenum content to a dangerous extent. Soil $B$, where a form of pining in cattle has been reported, but not definitely attributed to cobalt deficiency, carries a herbage which is initially guite high in molybdenum. Even $2 \mathrm{lb}$. cobalt chloride per acre causes a considerable increase in the molybdenum content of the herbage, and a content at which teart is liable to occur appears to be approached. It may be that the pining reported on this soil is a combined cobalt deficiency : molybdenum excess effect, and the addition of cobalt to the soil as a remedial treatment may have deleterious results. It appears from the work of Ferguson, Lewis and Watson that the uptake of molybdenum decreases with increasing soil acidity : the use of a cobalt-rich lime, as has been suggested in New Zealand, may therefore be dangerous.

In cases of cobalt-deficiency pining such as that occurring on soil $A$, the application of a cobalt-rich fertilizer is a simple and effective means of counteracting the disease, but it is evident from the foregoing that caution must be exercised in the general use of cobalt-rich fertilizers. More detailed investigation of the inter-relationships of cobalt, molybdenum and other trace constituents which appear to enter into the nutritional balance of the plant and the animal is necessary, and work on these lines is continuing.

COBALT AND MOLYBDENUM CONTENTS OF HLRBAGE, FIFTEEN MONTHS AFTER COBALT TREATMENT, AS PARTS PER MILLION OF DRY MATTER.

\begin{tabular}{ccccc} 
& \multicolumn{2}{c}{ Herbage from } & \multicolumn{2}{c}{ Herbage from } \\
$\mathrm{CoCl}_{2} 6 \mathrm{H}_{2} \mathrm{O}$ added & \multicolumn{2}{c}{ Soil $A$. } & \multicolumn{2}{c}{ Soil $B$} \\
lb./acre & $\mathrm{Co}$ & $\mathrm{Mo}$ & $\mathrm{Co}$ & Mo \\
0 & $0 \cdot 08$ & $1 \cdot 7$ & $0 \cdot 07$ & $6 \cdot 3$ \\
2 & $0 \cdot 22$ & $2 \cdot 2$ & $0 \cdot 20$ & $9 \cdot 2$ \\
10 & $0 \cdot 63$ & $2 \cdot 4$ & $0 \cdot 89$ & $10 \cdot 0$ \\
80 & $3 \cdot 20$ & $7 \cdot 5$ & $2 \cdot 75$ & $14 \cdot 2$
\end{tabular}

R. L. MitCheLL.

R. O. SсотT.

A. B. STEWART.

Macaulay Institute for Soil Research, Aberdeen.

JAMES STEWART.

Animal Diseases Research Association, Gilmerton, Midlothian.

Nov. 21.

${ }^{1}$ Askew, H. O., and Dixon, J. K., N.Z. J. Sci. Tech., 19, 317 (1937).

${ }^{2}$ Stewart, J., Mitchell, R. L., and Stewart, A. B., Emp. J. Expt. Agric., 9, 145 (1941).

seallott's Hill Res. Bull., No. 1 (March 1940).

\section{A Factor in the Dispersal of Burdock (Arctium Lappa, Linn.)}

THE hooks on the involucral bracts of burdock, by clinging to passing animals, secure the removal to a greater or less distance of the fruits from the parent plant; but they do not secure the scattering from one another of the fruits contained in the burr itself. A chance incident that occurred some years ago, but which I have only recently investigated, enables me to suggest the means by which this desideratum is probably achieved. One of the boys. in a class with which I was studying hooked fruits happened, after pulling to pieces a burdock burr, to lean his cheek on his hand: within a few minutes he complained of intense irritation in the skin of his cheek, and soon there appeared on his face a rash like that caused by the hairs of some caterpillars. Some of the copious yellow dust that falls readily out of the ripe burr of this species had adhered to his hands, so I attributed the discomfort to this substance; but only now have I examined it microscopically.

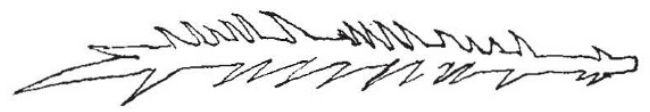

The microscope shows that the dust is composed of very fine and stiff bristles varying in length from approximately $1 \mathrm{~mm}$. to $2 \mathrm{~mm}$. and in breadth from $0.04 \mathrm{~mm}$. to $0.06 \mathrm{~mm}$. ; their distal ends are sharply pointed, and their sides armed with numerous short spikes, as illustrated. These bristles form a dense tuft (pappus) on the summit of each fruit, and their attachment to the ovary is so brittle when ripe that the slightest jar causes them to snap off and so lie free in the mouth of the burr. Their many needle-like points are certainly likely to irritate animal skin acutely.

I suggest that these pappus bristles are instrumental in bringing about the break up of the burr and the scattering of its fruits apart from one another. When a burr has become attached to the coat of an animal many of the bristles are certainly shaken out, and some, probably many, will reach the animal's skin, irritating it and causing the creature to scratch at the burr and in so doing knock it in pieces and fling the fruits fairly wide apart from one another.

The Elms,

OsWaLd H. LATTER.

Charterhouse Road,

Godalming.

Nov. 22.

\section{Ascorbic Acid System in Barley}

SzENT-GyöRGYI suggested that ascorbic acid might play a part as hydrogen-transporter in some tissue respirations comparable with the role of cytochrome. This was supported by the discovery of an active ascorbic oxidase in a number of plant tissues. A difficulty which has hitherto retarded acceptance of Szent. Györgyi's suggestion has been the failure to discover any cellular reducing system, other than glutathione, capable of regenerating ascorbic acid from its oxidized form.

Though barley tissues do not yield any striking reaction for glutathione, they are well known to contain ascorbic acid and they also contain a reducing system which we found would readily reduce methylene blue. By manometric methods we were able to show the presence of an active ascorbic oxidase, freely soluble in diluted barley sap or phosphate buffer at $p \mathrm{H} 6$. It was completely inhibited by $M / 1,000$ cyanide and had other characteristics similar to the ascorbic oxidase previously extracted from other plants.

In searching for a hydrogen-donator which would maintain the activity of the system, we found that addition of $M / 100 \rightarrow M / 20$ lactic acid greatly increased oxygen consumption, although in barley sap without addition of ascorbic acid it had no effect. Titration with 2, 6 dichlorophenolindophenol showed that the presence of the lactic acid maintained the ascorbic acid in the reduced form. At the end of 